\title{
'Out of the Shadows?' Accounting for Special Purpose Entities in European Banking Systems
}

\author{
MATTHIAS THIEMANN \\ Columbia University, Department of Sociology
}

This article focuses on national variations in the engagement of banks in off-balance sheet securitization in three case study countries: Spain, France and Germany. It is argued that the failures in prudential regulation that underpinned the recent financial crisis are not predominantly situated at the international level. This article focuses on the way that national accounting rules determine whether the Special Purpose Entities of banks are off- or on-balance sheet. The analysis shows that national accounting norms are an important building block for prudential regulation, and these are prone to wider political influences.

KEYWORDS banking regulation, consolidated accounts, special purpose entities, shadow banking accounting reform

\section{Introduction}

The state and other rule makers produce regulations or institutional innovations in order to limit negative externalities (Polanyi, 1944). However, this raises a question regarding what happens if such institutional innovations themselves are directed at circumventing regulations or, as Streeck puts it, if 'capitalist actors [act] as rational-utilitarian exploiters of gaps in rules'? (2010: 15 ). This article focuses on one such innovation - the securitization of assets in financial markets with the help of Special Purpose Entities (SPEs). SPEs are legal entities (usually set up in the form of a trust) created to fulfil narrow, specific or temporary objectives of the company that creates them. This article argues that the way in which financial actors used this innovation at a national level before 2007 was significant in relation to the impact of the global financial crisis on national banking systems. Responding to this innovation required the active steering of banking regulators in remodelling national accounting norms and influencing the interpretation of international accounting norms.

In generating vital financial data about risk-taking in the financial sector on which banking regulators can act, accounting is a fundamental for prudential regulation. 
(Zeitler, 20IO). In particular, national accounting norms for the consolidation of subsidiaries into the balance sheet of banking conglomerates is a critical point for the stability of the financial system, as was revealed by the last financial crisis. The paper examines the evolution of these accounting rules from I998 to 2009 in relation to banks from three large economies of the European Union (EU) - Germany, France and Spain - in a specific segment of the capital market, the Asset-Backed Commercial Paper Market (ABCP market). In this segment, banks sponsor SPEs to issue shortterm commercial paper, often constructing them in such a way as to be outside of the banking groups' balance sheet.

The hypothesis that informs this article is that the speed and degree of convergence of national norms of consolidation to international norms were a decisive differentiating factor in the impact of the global financial crisis on different European banking systems. National financial accounting standard setting was the intervening variable in the process of convergence of international norms. Bank regulators have shaped national financial accounting rules by pushing for the adoption of international financial reporting standards in order to constrain unruly off-balance sheet assets by banks in prudential regulation. If banks were forced to account for the risks to which they were exposing themselves in capital markets, they would not engage in proprietary trading off-balance sheet and would therefore not accumulate excessive risks off-balance sheet. In focusing on this hypothesis, this article investigates the following question: What influenced the formation of financial accounting rules with respect to off-balance sheet financing and their translation into prudential regulation in these three different European countries?

The data is drawn from both primary and secondary sources. Forty-six semistructured interviews were undertaken with key economic agents. This included central bankers, financial regulators, senior bankers engaged in asset management, the securitization business and accounting policy, auditors, employees of national and the international standard setting body, and different rating agencies. The interviews took place between August 2010 and July 20 I I and focused on the political struggles over the reform of national accounting rules regarding the consolidation of SPEs and their impact on the ABCP market.

The article is structured as follows. In the next section the specificities of the recent financial crisis are outlined and the gaps in recent political science literature on banking regulation will be discussed. The impact of the financial crisis on the three case study countries is then discussed and related to the presence and activities of banks in the asset-backed commercial paper (ABCP) market. After explaining how the imposition of international capital requirements contributed to the growing use of SPEs, the article proceeds to discuss the legal structure of SPEs and their relationship to accounting rules. The article goes on to explain why regulation of the International Accounting Standards was the most restrictive in the Western world and how the European framework for accounting delayed its adoption in different European countries. The last part of the article focuses on the convergence of domestic standards with International Accounting Standards in the three case study countries and the obstacles they faced for using the information generated in prudential regulation. As will be seen, the actions of these regulators were constrained by national pathdependent accounting frameworks and a differentiated involvement in accounting standard setting of financial regulators in these different national frameworks. 
With regard to the selection of case study countries, Spain and Germany serve as two extreme cases. Whereas in Spain the financial regulator has total responsibility for formulating accounting rules for banks, in Germany the financial regulator has none. France lies in-between the two, with a leading participation of the French prudential regulator in standards that concern the banking sector. The last two sections are devoted to the discussion of the findings and the conclusions.

\section{The financial crisis and the literature on banking regulation}

In order to fully grasp the nature of the 2007 financial crisis, it is necessary to appreciate that it was first and foremost a crisis of loan defaults amplified by a process of securitization, an off-balance sheet activity of banks, which was part of the shadow banking system (Blundell-Wignall \& Atkinson, 2010). The supposed credit risk transfer, in which banks had engaged by selling assets to the shadow banking sector where they were securitized, turned out to be illusory. Banks were not only the main sponsors of the shadow banking system, which was responsible for securitization, but also bore the majority of risks. They had manoeuvred many of their assets off-balance sheet and linked them to the capital markets via SPEs only to take them back on the balance sheet when perceptions of risk changed abruptly in the market (Acharya \& Schnabl, 2009; Heilpern et al., 2009).

This sudden appearance of assets on the balance sheets of banks that, prior to the crisis, had been understood to be removed from their balance sheets was a prime factor in accelerating and amplifying the financial crisis. Investigating the regulatory failures related to the financial crisis requires an analysis of how these banks could both engage in off-balance sheet activities and avoid consolidating shadow banking subsidiaries. A partial explanation lies in accounting norms, which regulate the recognition of assets on the balance sheets, and how risk is calibrated once they are on balance sheets and subject to Basel 2 regulations. ${ }^{2}$

Looking at the crisis from the perspective of the engagement of banks in capital market operations via SPEs reveals a very high participation of European banks in the off-balance sheet asset-backed commercial paper market (Arteta et al., 2009; Acharya \& Schnabl, 20Io). After the onset of the financial crisis, this left many banks holding securitized assets, which before had been transferred to SPEs (Covitz et al., 2009). The problem with many of these assets, including collateralized debt obligations (CDOs) and residential mortgage-backed securities (RMBS), was the contamination of risk as these assets generated some of the sharpest losses in value during the crisis (Heilpern et al., 2009). Therefore, the off-balance sheet activities of banks are crucial to understanding the magnitude of the crisis (Financial Stability Forum, 2008; Acharya \& Schnabl, 2009, 20I0; Covitz et al., 2009; Jouyet, 2009; Noyer, 2009).

There is an under-appreciation of the role and importance of financial accounting for banking regulation in general, and more many studies neglect the interaction of national regulators with international conventions. Much literature on banking regulation has devoted itself to the analysis of the international agreements of the Basel Committee, which were seen as establishing global standards, thereby overcoming domestic industry resistance to tighter prudential regulation (Reinicke, I995). 
These developments were initially welcomed as creating a level playing field between banks, but many academic observers of the political economy of financial markets have described this policy process as lacking democratic legitimacy (Underhill \& Zhang, 2008) and as unduly influenced by bank lobbying. The Basel 2 agreement, in particular, has been criticized as being shaped by the large banks (Tsingou, 2004, 2008; Helleiner and Porter, 2009) with some scholars arguing that Basel 2 itself exacerbated the crisis (Underhill, 20I0). Such analyses of the problem of the evolution of banking regulation on the international level, however, risk underplaying the effort involved in the national implementation of international accords and the significant leeway still remaining for national regulators in dealing with their national banks. For securitization in particular, up until 2008 there was no adequate international securitization framework in existence and therefore every country had to make its regulations for dealing with securitization and re-securitization (Interview with Bundesbank, 20II).

Comparative political economists have strengthened the concept of state capacity in the realm of banking regulation to explain different national manifestations of the converging international regulatory framework (Moran, I99I; Coleman, I996; Busch, 2009). From this perspective, national institutions act as 'filters of globalization' (Busch, 2009), which exemplify differential state capacity in the realm of financial market governance. Such analyses confirm the importance of the role of interest groups and institutional structures of authority in explaining differential outcomes of national regulation (Busch, 2009). However, while securities markets, which were the epicentre of the financial crisis in 2007 and 2008, have become 'global', unifying most issuers, traders and buyers of debt in financial centres, the regulation of the permitted activities of banks and their prudential treatment have remained nationally determined and embedded.

Both the international political economy and critical political economy literatures have serious weaknesses in their focus on the material preconditions for the supervision of banking, where national rather than international regulation is of predominant importance. Instead of focusing on how banking regulators treat the data they receive according to certain international rules (rules of the Basel Committee, for example), the question becomes: which part of banking activity is actually reported to banking regulators and thus deemed to be within the ambit of these rules? This reporting is based on national rules, which adapt or otherwise to international standards.

\section{The different impact of the crisis and the $A B C P$ market}

The different impact of the crisis on the Spanish, French and German banking systems has been noted in both financial and academic circles (Hardie \& Howarth, 2009; Tieman, 2009; Aalbers et al. 20II). The French banking system incurred smaller losses and experienced fewer government interventions than Germany's (IMF, 2009). By the beginning of November 2010 , Germany had injected capital and granted credit lines to the value of $€_{4 \mathrm{I}} 7.5$ billion, while the French government had recapitalized banks and extended credit to the value of only $€_{25} .8$ billion; in the case of Spain, the equivalent figure was $€_{10.7}$ billion (Commission Bancaire, 2008; IMF 2009; R\&S, 20II). 
Figure I represents the engagement of banks according to their origin in the market segment of asset-backed commercial papers, which mostly has been off-balance sheet. Germany had the second-largest, after the US, exposure to the ABCP market $\$ 228$ billion in June 2007), while the domestic market in asset-backed commercial paper in that year accounted for no more than $\$ 35$ billion (Moodys, 2008). France, on the other hand, had $\$ 82$ billion in asset-backed commercial paper in June 2007, of which $\$ 30$ billion can be accounted for by domestic asset-backed commercial paper. Spanish banks had such a negligible ABCP exposure that they barely appear on the graph (Banco Santander is the only bank that had such a conduit).

Securitization techniques in the short-term paper market had been used by banks to facilitate the capital market access of their clients by offering to buy their credits and refinance them in the capital markets. The entities facilitating these transactions are called multi-seller conduits, and they dominate the global market (Figure 2). From 1999 onwards, another type of conduit gained prominence, the securities arbitrage conduit, which grew in value from \$56 billion in I999 to \$24I billion in 2006 (Moody's Program Index). These conduits no longer served clients or securitized loans the bank itself had originated. Instead, they provided a way for the banks to engage in securities arbitrage in capital markets by buying long-term assets and refinancing them with short-term paper. Hybrids mix the activities of multi-seller and securities arbitrage conduits, whereas single-seller conduits are vehicles through which the bank sells assets directly from its loan books to the conduits (conduits being the name for special purpose entities in the ABCP market). Here, the main purpose is to generate further liquidity for the bank, but banks can also use these structures for regulatory arbitrage.

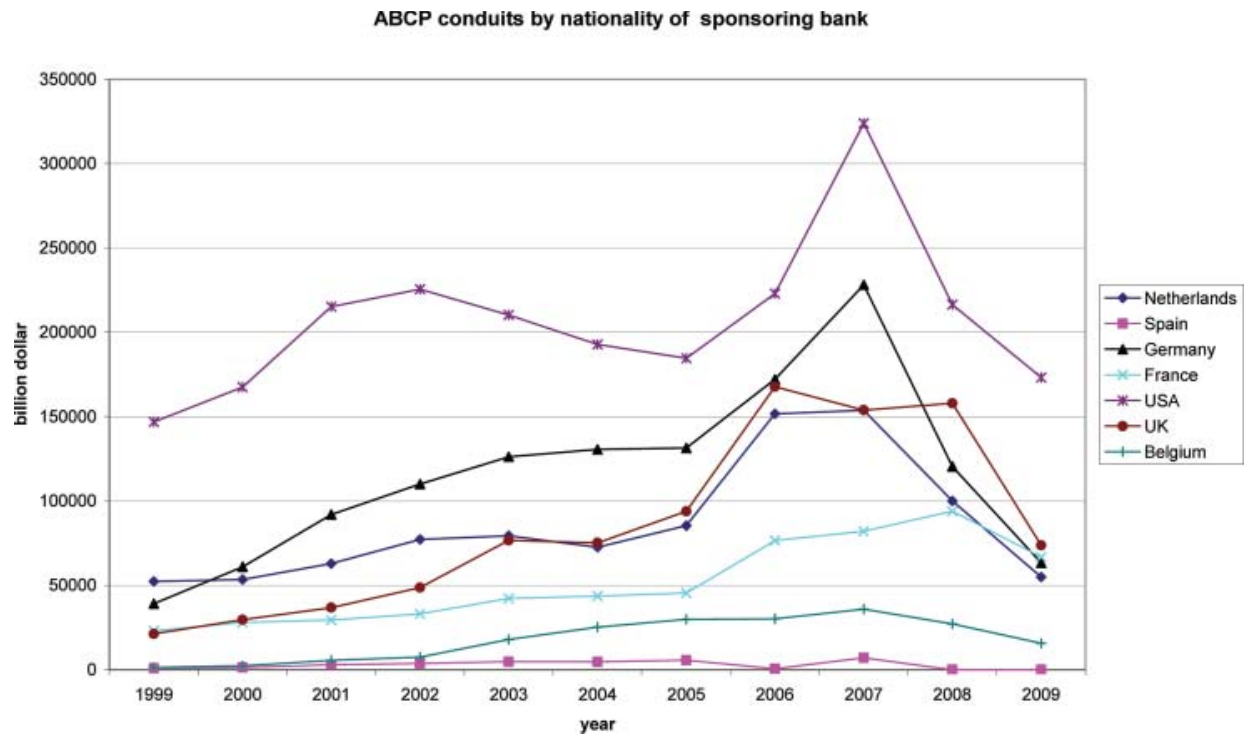

FIGURE 1 ABCP conduits by nationality of sponsoring bank.

SOURCE: Data from Moody's. 


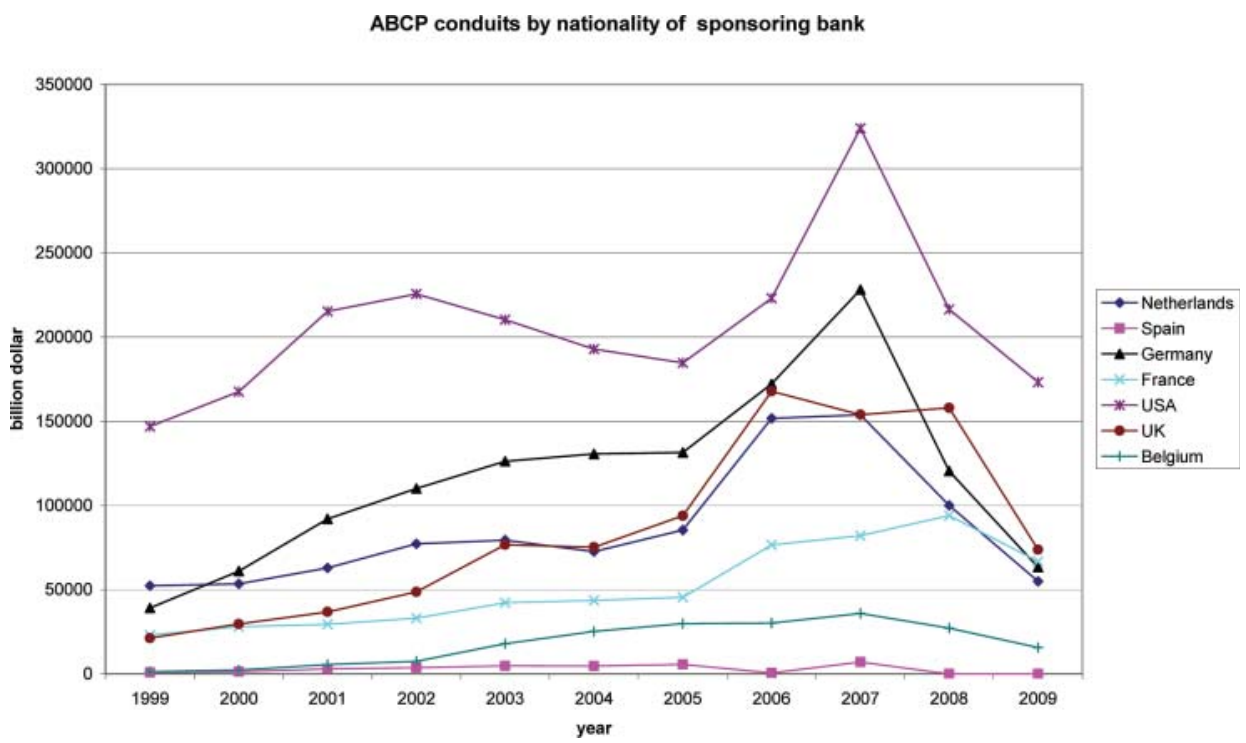

FIGURE 2 ABCP conduits by nationality of sponsoring bank.

SOURCE: Data from Moody's.

Seventy per cent of the volume of these securities arbitrage conduits was sponsored by EU banks (Figure 3), with German Landesbanken being especially active in this market (Pozsar et al., 20IO).

This large exposure in the securities arbitrage market proved to be a huge source of loss-making. When the conduits could not refinance their assets in capital markets,

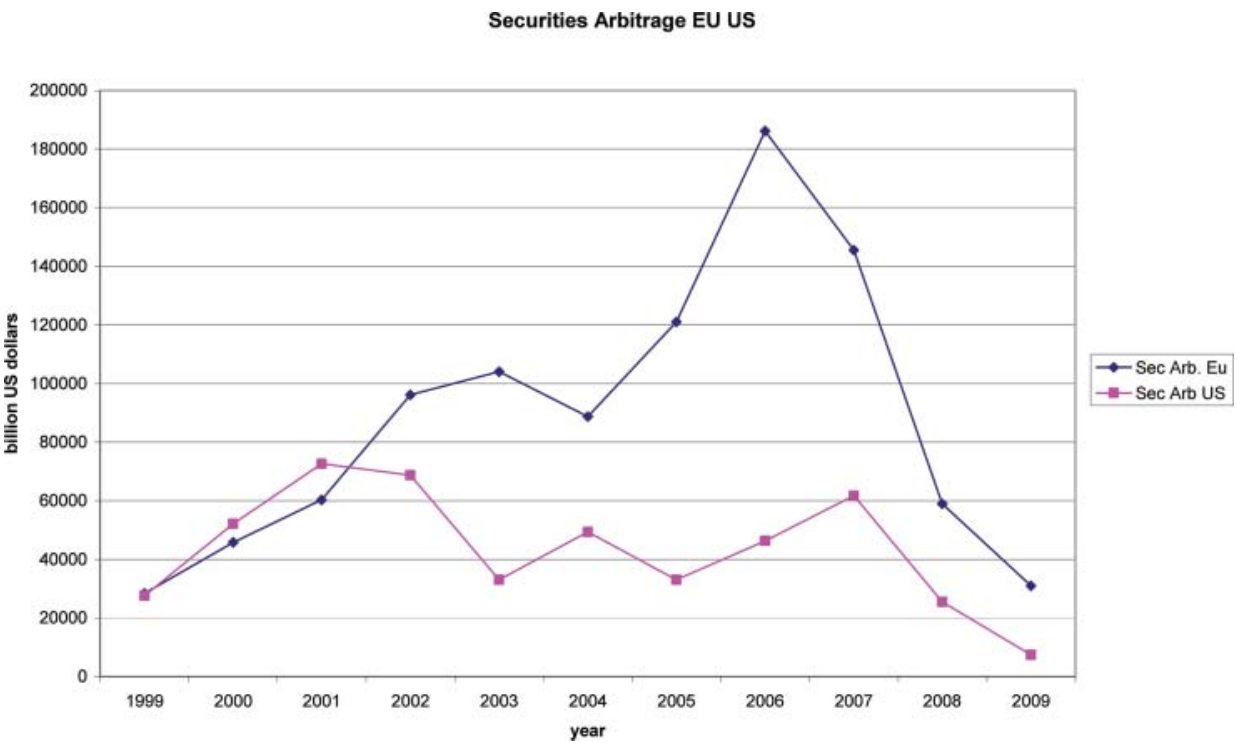

FIGURE 3 Securities Arbitrage Conduit Volume, US vs. Europe.

SOURCE: Data from Moody's. 
the banks had to take these assets back onto their balance sheets. Since the onset of the crisis in 2007 , the ABCP market experienced a decline of about 50 per cent over a two-year period (S\&P, 20IO), securities arbitrage conduits declined by between 67 and 74 per cent, while multi-seller conduits only declined by 38 per cent. ${ }^{3}$

The different exposure of European banks of different national origins to securities arbitrage conduits can be largely traced to different regulatory capital charges for conduit activities. Regulatory capital charges refer to the capital banks have to hold in highly liquid assets in order to be able to deal with the potential risks of the banking business without going bankrupt. These refer in particular to unexpected credit losses from assets that are deemed part of the banking group. ${ }^{4}$ Banks need to keep this capital in cash or other very liquid assets in order to deal with risk events quickly. Given these high liquidity needs, this capital generates little to no income. Therefore regulatory capital requirements are costly to banks in the sense that they cannot employ the money in a more profitable way (opportunity costs). Given the small margins that were earned in engaging in securities arbitrage conduits, banking regulators could discourage banks from operating in this market by applying capital charges to their activities. The extent to which banking regulators could do this was limited by the degree of modernization of national accounting rules. Modernization here is used normatively as the ongoing adaptation of accounting rules to limit the misuse of accounting rules by firms to artificially improve the accounting information they provide to financial markets. ${ }^{5}$ In the case of this article, this misuse involved the creation of SPEs by banks to legally transfer assets to them that, in economic substance, remained assets of the bank.

Regulatory capital charges are calculated using the accounting numbers provided by national accounting rules. If these were not modernized with respect to SPEs, they were incapable of capturing the assets placed into SPEs as assets of the banking group. As a consequence, these assets would not be taken into account for the calculation of regulatory capital charges. Therefore no regulatory capital could be charged for the possibility of unexpected credit losses of these assets. But unexpected credit losses on the kinds of asset that were placed into these SPEs were the main drivers of the financial crisis. This explains the amplifying impact these assets in these SPEs had on the banking system, as the precautionary measure of regulatory capital charges were not applied to them before the crisis. The banking system was in essence not prepared to deal with the unexpected credit losses of these assets, which in legal form had been transferred out of the banking system.

The following section discusses the technicalities involved in transferring these assets legally from the balance sheets of banking groups to SPEs, while these banking groups maintained control over them in economic substance. The discussion will show how accounting rules shaped the behaviour of banking groups, as accounting decisions were central to the business model of securities arbitrage conduits.

\section{Regulatory capital requirements and the business model of securities arbitrage conduits}

If banks are deemed to control another entity (such as an ABCP conduit), the assets of that entity appear on the balance sheet of the banking group and the banking 
group that is then forced to account for the 'riskiness' of those assets by building up additional capital reserves. The calculation of required capital reserves in the Basel regime is applied to the assets of the banking group, which includes all entities under the direct control of the bank and that are engaged in business related to banking. Therefore, whether or not a bank has to consolidate an SPE on the balance sheet of the banking group can have a decisive impact on the decision of the bank to establish the SPE in the first place (Interview with senior manager in German bank, 20II).

Securities arbitrage conduits impacted favourably on required capital reserves in three ways. First, the bank could reduce the regulatory capital reserves, which they needed to hold. Second, banking groups that engaged in SPEs kept most of the revenues generated by the SPEs by making them pay fees for services to the sponsoring bank. These services included the selection of assets to be bought by the SPE, the collection of revenue from the assets held by the SPE and the pay-out of interest to investors of the commercial papers. Thus the entire business activity of the SPE was outsourced to the bank. Third, and as a consequence of these two effects, the return on equity for banks improved (in some cases, such as that of the IKB Deutsche Industriebank AG, markedly) as a consequence of this off-balance sheet activity. ${ }^{6}$

For these reasons, off-balance sheet securities arbitrage conduits were extremely attractive for banks, especially for those with poor returns on equity (Haensel \& Krahnen, 2007; Bannier \& Haensel, 2009). The margins for this form of 'proprietary trading outside of the banks' balance sheet' (Interview with German banker) are, however, not very high (Acharya \& Schnabl, 2009; Acharya \& Suarez, 2009, Hellwig, 20I0). While exact margins are not known, they are estimated at between Io and 30 basis points $^{7}$ (Hellwig, 20I0: 27), which creates the need to trade in large sums. An effect of this low profitability is that, if banks are forced to hold regulatory capital in liquid, low-return assets to cover the unexpected losses of the assets placed into these conduits, these entities become unprofitable as a result of the high opportunity costs of regulatory capital (Hellwig, 2010: 26).

Thus, banks with poor margins engaged in keeping assets and the SPEs off-balance sheet to manipulate earnings and regulatory capital requirements. However, at the same time that they were keeping these assets off-balance sheet, they wanted to maintain control over the assets they transferred to the SPEs, which involved an exercise in law-abiding regulatory circumvention. While formally the assets were the property of an independent SPE, they remained under the control of the banks. In order to achieve these advantages, banks needed to organize their contractual relations with the SPE such that it was not seen as part of the banking group. The following section examines how this demarcation was organized.

\section{Determining the scope and boundaries of a banking group}

Accounting rules have to determine if the relationship between cooperating firms equals a conglomerate, i.e. if the observed contractual and business relationships between the firms justify referring to it as a parent firm and its subsidiaries. The decisive question is whether the parent company controls the subsidiary such that it has no latitude in choosing its own strategy. All of these subsidiaries and their assets then need to be factored into the consolidated accounts of the parent company. The 
financial ratios calculated from consolidated accounts, such as the equity to debt ratio, have a strong impact on the interest rates conglomerates have to pay when borrowing in financial markets, as these numbers are used to gauge the viability of the firm.

For banking groups, these consolidated accounts have an additional importance, as regulatory capital requirements are calculated on their basis. As such, there is a significant incentive for banking groups to structure and adapt their contractual relations to subsidiaries in such a way as to keep them outside of the perimeter of the banking group in order to optimize their equity to debt ratio and their regulatory capital requirements. This is the reason why the question of the consolidation of conglomerates has a particular importance for banks and provides an incentive for them to structure their business activities in a particular way. Indeed, there is an entire 'cottage industry' of legal firms and accountants engaged in selling contractual models to banking groups in order to achieve the desired off-balance sheet effect. These contractual models represent legal innovations, engineered to circumvent the classification of subsidiaries as being controlled according to accounting standards. The objective is to employ accounting disclosure rules relating to banking groups to circumvent regulations, as core capital charges are mostly applied to assets on the books of the banking group.

In order to remove assets from its balance sheet, banking groups need to engage in a 'true sale' of the assets, which implies that none of the risks or benefits related to the asset remain with the vendor. Thus selling assets to an SPE needed to imply that neither the risks nor the benefits of these assets remained with the bank, which was achieved by making the SPE bankruptcy remote from the banking group. While fulfilling these requirements legally, in substance banks were exposed to the risks and benefits of these assets. In order to maintain control over the revenues generated by the assets in the SPE, the banks undertook all the business activity of the SPE for fees and provided liquidity guarantees in case of the SPE experiencing difficulty selling its short-term debt, thereby swapping the exposure to the assets to an exposure to the SPE (Gorton \& Souleles, 2006). The assets, now sold and off-balance sheet for the banking group, were now situated on the books of the SPE. The next financial 'innovation' was to ensure that the SPE was not consolidated as a subsidiary of the bank.

Before 1998 in the US and Europe, the rules for consolidation in accounting terms maintained that a company needed to consolidate a subsidiary company in which it held the majority of shares and/or controlled its business strategy. Accounting norms stated that the control of the business had to be visible in the daily operation of the firm. The banks designed 'autopilot mechanisms' in order to control SPEs while avoiding consolidation of them in their balance sheets. These specified that SPEs could not sell or buy assets on their own; rather, the investment advisor (the bank) made the investment decision (these are called service-level agreements). Furthermore, banks usually held no shares in the SPEs and this legal engineering led to a very specific organizational structure for SPEs:

In short, SPEs are essentially robot firms that have no employees, make no substantive economic decisions, have no physical location, and cannot go bankrupt (Gorton \& Souleles, 2006: 550). 
Banks thus constructed SPEs in order to displace assets from their balance sheets and to avoid the consolidation of SPEs themselves, while continuing to benefit from the assets parked in these entities in terms of income, profit and lower equity requirements. In the US and the UK, reaction to this legal innovation was muted, even after the debacle of the energy company Enron, whose failure was partly the result of the 'creative use' of SPEs to 'massage' balance sheets. Changes in regulation in the US and in the UK after Enron were driven by the search for a compromise to allow further securitization through off-balance sheet financing (Jeffrey, 2002). Qualifying SPEs for securitization were exempted from consolidation in US law (according to the accounting rule Fin I40), while the accounting rule in the UK, called 'linked accounting', made most of the assets disappear from the balance sheets of banks. Only the International Accounting Standards forced banks to consolidate many of their SPEs onto their balance sheets (Jeffrey, 2002: 349).

The regulatory innovation that was explicitly aiming at and capable of capturing SPEs was Rule 12 of the International Accounting Standards Interpretation Committee (hereafter called SIC I2) in 1998 (Larsson, 2008). According to this rule, autopilot mechanisms explicitly qualified as a means of exerting control and the interpretation emphasized economic substance over legal form in the relationship between the SPEs and the banks. Notwithstanding the lack of shares in the SPE, if a bank maintained the majority of risks and rewards stemming from that entity and/or exercised direct control over it, then it had to be consolidated. Lobbyists such as the European Securitization Forum complained that almost no off-balance sheet financing is possible under International Accounting Standards (IASs) and lobbied the International Accounting Standards Board (IASB) to repeal SIC I2 as they purported that it endangered the economic benefits to be had from securitization (European Securitization Forum, 2002).

Nonetheless, in 2002, the European Union committed itself (Regulation (EC) No. I6/2002) to introducing the International Accounting Standards, and with it the rules for off-balance sheet financing from 2005 onwards for all listed companies and in 2007 for all companies issuing securities in financial markets. However, despite the introduction of the IASs, off-balance sheet financing continued to grow strongly in Europe after 2005. In some countries, this counter-intuitive development resulted from the fact that the off-balance sheet treatment of SPEs was based on national accounting rules for consolidation, which, if not brought into line with international or European accounting standards, could not detect SPEs (as in the case of Germany).

In other countries, the difference between national accounting rules for the consolidation of international accounting rules diverged to such an extent that banking regulators in EU countries wanting to put small private and large public banks on a level playing field abandoned any use of this accounting information. Instead, they implemented a prudential filter from 2006 onwards (as in the case of France; Amis \& Rospars, 2005: 48f, 58), which explicitly disregarded the on- or off-balance sheet status of SPEs. Therefore, effective prudential regulation was based on a process of convergence of national accounting norms to the International Accounting Standards, a process that was constrained by the European accounting directives. The EC Directive of 1983 on consolidated accounts (83/349/EEC) stated in Article I.2 that: 
the Member States may require any undertaking governed by their national law to draw up consolidated accounts and a consolidated annual report if that undertaking (a parent undertaking) holds a participating interest as defined in Article I7 of Directive 78/660/EEC in another undertaking (a subsidiary undertaking), and it actually exercises a dominant influence over it (Seventh Council Directive 83/349, Council of European Communities I983:2).

Therefore a capital link between the parent and the subsidiary, which was required for consolidation of the subsidiary, does not exist between an SPE and a bank. It was not until 2003 that the European Directive dropped the requirement that the parent undertaking holds a participating interest in order to allow for consolidation. Instead, the changes made require that an 'undertaking (a parent undertaking) has the power to exercise, or actually exercises, dominant influence or control over another undertaking (the subsidiary undertaking)' (European Parliament and of the Council Directive 2003/5I EC, p. 4). Dropping the requirement of a participating interest and introducing the notion of 'the power to exercise' in June 2003 allowed for the consolidation of SPEs in which the sponsoring banks did not have any participating interest. However, this was not mandatory for member states. The degree to which this was adopted depended on the distribution of competencies in the regulatory network, as well as on the distribution of political-economic power. When banking regulators had as one of their competencies the direct supervision of the accounting decision of their supervised banks, their accounting departments provided the knowledge needed to understand the impacts of accounting rule changes for prudential regulation early on.

As we shall see in the next section, the dimension of political power is important regarding which actors with what powers were included in the process of accounting standards.

\section{The case of Spain}

In Spain, the banking regulator, the Banco de Espana (BdE), has the right to make accounting rules for the banks. De facto it interpreted the International Financial Reporting Standards in such a way that achieving off-balance sheet status for ABCP conduits was made almost impossible. It did so following Directive 2003/5I/EC of the European Parliament that permitted countries to require consolidation of SPEs even without a capital link between them and their sponsoring banks, by issuing new accounting rules in 2004. Banks had approached the Banco de Espana and requested permission to set-up securities arbitrage conduits. However, the regulator, who was already concerned about the extensive growth of mortgage credit in the economy, refused to allow this innovation (Tett, 2008). ${ }^{8}$

The decisive document is Circular 4 of the Banco de Espana issued in 2004. This went beyond the treatment of securitization in the new Basel 2 framework. Rather than simply applying the securitization framework of 'significant and substantial risk transfer', which had to be achieved for the de-recognition of assets, the Banco de Espagne took into account the balance sheet of the financial holding company in its entirety, including SPEs.

'In consolidated financial statements, the criteria set out in the above paragraphs for de-recognizing financial assets shall be applied after fully consolidating all the 
subsidiaries. In particular, the circumstances referred to in paragraph $\mathrm{I}(\mathrm{b})$ may arise in transfers to special purpose entities defined in paragraph 5 of Rule forty-six fully consolidated in the group, such as securitization special purpose vehicles' (Banco de Espana, 2004: 55).

In addition, they added a third category to the decision tree of the auditor, which applies when 'the risks and rewards associated with ownership of the asset are neither transferred nor retained substantially'. In this case, the accountant is asked to focus on the cash flows as well as the capacity of the SPE to sell the assets without the consent of the sponsor (Ybanez \& Garcia-Fuertes, 2005). This last requirement clearly contradicts the construction of an SPE in which the bank wants to maintain control over assets while legally transferring them. Finally, if there are doubts on the part of the auditor, he or she is requested to err on the side of consolidation.

'When it is difficult to conclude whether the risks and rewards of the financial assets have been transferred substantially or significantly, or when the various elements of analysis considered individually indicate that the risks have been transferred, but considered together do not permit that conclusion so readily, the transfer shall be classified as one in which the risks and rewards have been retained substantially' (Banco de Espana, 2004: 52).

As a result, from 2004 onwards, when the overall volume of ABCP conduits grew strongly (Figure I), Spanish banks were de facto regulated out of the market for all securitizations (Tett, 2008). The Spanish regulator thus acted forcefully to include SPEs in the perimeter of accounting and of prudential regulation.

\section{The French case}

In France until I998, accounting rules for banks were also written under the auspices of the banking regulator in the Comité de la Règlementation Bancaire et Financière. In 1998, large-scale reform of the accounting process in France was finalized, consolidating all accounting rule-setting power in the Conseil National de la Comptabilité (CNC; National Council of Accounting). After this reform, the French banking regulator became a member of the $\mathrm{CNC}$, operating under the principle of including all stakeholders concerned with accounting rules in the process of rule-setting in a collegial manner. While the banking regulator lost its exclusive power over accounting standards, institutional changes at the CNC also favoured rapid convergence with the International Accounting Standards. In reforms in 1996 and I998, the membership of the CNC was reduced by half and gained standard-setting powers. Formerly, the CNC could only issue advice and depended on the translation of this advice into regulations by the government. Furthermore, the new president of the CNC ceased to be a former state employee and instead came from one of the big international auditing networks; as a former president of the International Accounting Standards Committee, he favoured speedy convergence with the international standards (Interview with Order of French Accountants, Paris). The fact that the French banking regulator was so centrally involved in the standard-setting process guaranteed that these standards were in accordance with prudential preferences, 'to make banks account for the risks they take' (French Banking regulator, Paris).

In the CNC there is a sub-committee for financial entities, where auditors, financial regulatory agencies and the banks negotiate new rules. In I999, the rules for 
consolidation were reformed. The first rule, CRC 99-02,9 applies to all companies, except for banks and insurance companies; it is almost identical to SIC I2, but requires a capital link between parent and subsidiary and that both the majority of risks and rewards are with the sponsor. In SIC I2, the majority of either is sufficient. The second rule, CRC $99-07,{ }^{\text {IO }}$ applies only to banks and insurance companies and drops the capital link. In order to achieve this almost-complete convergence with SIC I2, the French banking regulator used an option in the seventh directive in Article I.I(c), which states that 'a member state need not prescribe that a parent undertaking must be a shareholder in or member of its subsidiary undertaking'. ${ }^{\text {II }}$ This directive implies that those countries that did not require a capital link before I983 for consolidation did not need to change their accounting rules. In the case of France, the Commission Bancaire argued, accounting rules for banks were not part of general accounting rules until I998. Thus the banking regulator could argue that the banking accounting norms did not fall under the general French accounting framework, which had required such a link (Interview at the CNC, Paris, 30 January 2 oII; see also Bulletin Officiel du CNC n ${ }^{\circ}$ II9, I999: $9^{\mathrm{I} 2}$ ).

Regarding this specific rule, the prudential regulator headed the rewriting of the rule, fighting in the sub-committee of the CNC to make the standard for off-balance sheet accounting as strict as possible (Interview with accountant of a big four company in Paris, former member of the CNC). French accounting norms, as applied to credit institutions, were therefore almost the same as SIC I2 in I999. In September 2000, the Comité de la Règlementation Bancaire et Financière, headed by the president of the Banque de France and the president of the Commission Bancaire, translated this accounting norm into prudential regulation in the 'Règlement $n^{\circ}$ 2000-03 relatif à la surveillance prudentielle sur base consolidée'. ${ }^{\mathrm{I} 3}$ Thus, using the information generated by the accounting norms for prudential regulation made the engagement of French banks in the ABCP market more costly than for the US, Britain or Germany. The real impact of the rule, however, was only felt once its interpretation had been made more stringent by a joint statement of the banking and securities regulator in France in November 2002. This requested consolidation only if the majority of risks resided with the banks, as they argued that this implied that the majority of rewards also resided with them. ${ }^{\text {I4 }}$ This required restructuring on the part of banks with respect to the distribution of risks and a reduction in their margins (Interview with French bank). Accordingly, the number of securities arbitrage conduits decreased from nine in I999 to five in 2002 to zero in 2006 (Moody's Program Index).

As a consequence, French banks were engaging in multi-seller conduits, providing access to the capital markets for their clients, but had no exposure to securities arbitrage conduits in 2007. In accordance with this view, a French banker pointed to the low margins as the main reason for the small number of ABCP conduits of French banks (Interview with senior banker, Paris, 24 March 20II). French banking regulation thus facilitated beneficial innovations regarding securitization, while making its use for off-balance sheet proprietary trading more difficult.

\section{The German case}

In Germany, prudential regulation regarding the build-up of core capital for the assets of banking conglomerates is directly linked to the consolidated accounts created 
according to the German accounting rules as established in the code of commerce. The Kreditwesengesetz $\mathbb{I}$ I, Nr. 7 explicitly refers to the German accounting rules for consolidation. This linkage of (non-modernized) commercial law and credit law translated into a total de-recognition of assets in SPEs in prudential terms up until the German Accounting Law Modernization Act (Bilanzrechtsmodernisierungsgesetz), modernizing the accounting rules in 2009 (Interview with Bundesbank officials, August 2010). This process of modernization began in 2002, to be completed seven years later. The long delay and large resistance to more stringent accounting rules with respect to off-balance sheet financing is partly the result of the fact that, in contrast to Spain or France, there has never been a separate accounting regime for banks. In Germany, a single set of accounting rules applies to all firms, which means that changes to the rules for consolidation, and thus for off-balance sheet financing, concern all groups engaged in off-balance sheet financing. The delay is therefore the result of an economically and politically entrenched opposition and a splintered framework for accounting rule-setting whereby there were many points at which proposed changes could be vetoed (Interview with accountant of big four company working on the German accounting modernization Act, 30 May 20II). Indeed, the institutional framework concerning the standard setting for accounting norms was entirely different to and much less developed than that in France. Before 1998, there was no specific standard-setting body for accounting norms; instead, changes to the accounting norms in German commercial law were handled entirely by the Ministry of Justice.

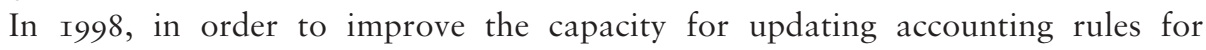
consolidated accounts to international standards and in order to have influence at the International Accounting Standards Board, a new law permitted the Ministry of Justice to sign a contract with a private body - the German Council for Standardization (DRSC), whose role was to offer advice on improving rules for consolidated accounts. Crucial differences between the German and French standard-setting bodies reside in their respective legal capacities to change accounting standards and the role in the process of rule formulation. In Germany, the Ministry of Justice is the final arbiter on rule changes. In addition, the German standard setter is not the only advisory body, as the Ministry of Justice is required by law to consult with the federations of industrial and commercial enterprises in the law-making procedures (common procedures of the German ministries ${ }^{15}$ ), thereby creating a rivalry between these federations and the standard-setting council. This peculiarity of norm setting in Germany gave federations more veto power to stave off the more restrictive rules regarding off-balance sheet financing.

Delay became evident when the standard-setting council pushed for the first time for convergence of German accounting rules with SIC I2. When Enron failed in 200I, the standard-setting body began intense lobbying for convergence ${ }^{16}$ and issued a draft for a new consolidation standard. Reactions were mixed; leasing firms and the Federation of Chief Financial Officers virulently opposed the changes as introducing 'contested accounting rules' into German standards and criticized the endangering of the leasing business model.

In a remarkable deviation from its French counterpart, the German banking supervisor, the Bundesanstalt fuer das Kreditwesen (BaKred, precursor to the Bundesanstalt fuer Finanzdienstleistungsaufsicht) was lobbying the Ministry of Justice directly on this 
issue and urged a longer rethinking of complex legal changes involved in treating the autopilot mechanism. ${ }^{17}$ In addition, the letter of BaFin alludes to the fact that changing the rules for consolidation might have an impact on the core capital of banks in prudential regulation, the exact size of which could not yet be estimated.

The German standard-setter continued to push for a change in the consolidation rule according to SIC I2 from 2002 onwards, culminating in the proposal for the modernization of the code of commerce in May 2005. This did not succeed. Even in the first and second drafts of the law for the modernization of the code of commerce, in 2007 and 2008, no changes to the criteria for consolidation were envisaged. Only in the aftermath of the crisis, because of the magnitude of the shock and the political weight given to this question, did the Ministry of Justice agree to converge the rules for consolidation with those of SIC I2. This move came as a total surprise to the banking industry (Interview with senior management of large German bank, Frankfurt, I2 July 20II). An interviewee involved in writing the accounting modernization law (Berlin) stated that, without the crisis, these changes would never have happened because of the resistance of large industry associations. It took significantly longer for German accounting norms to converge with international standards as compared with France and Spain. German banks did not need to account for the risks they built up off-balance sheet (Bundesbank, 2008), which enabled German banks to sponsor large-scale securities arbitrage conduits. The two conduits with the most devastating consequences for their banks were the Rhineland Capital Funding and Ormond Quay Funding, established in 2002 and 2004, respectively.

Why did the German financial regulator not oppose these developments and ally itself with the DRSC in demanding accounting rule changes, which would have directly led to capital charges for these conduits? Simple regulatory capture might have played a role, but more important is the relationship between the Bundesanstalt fuer Finanzdienstleistungsaufsicht and the German finance ministry and the specific importance of off-balance sheet financing for the German economy in the 2000 s. BaFin is subordinated to the German finance ministry. The finance ministry itself, however, had been engaged since 2003 in a campaign for enlarging ABCP programmes to finance German 'Mittelstand' (small and medium-sized enterprises). The use of SPEs in ABCP and leasing programmes kept tens of billions off the balance sheets of German firms, improving their financial ratios. This and the fee income for banks were the drivers for the pro-securitization stance of the German finance ministry (Asmussen, 2006).

\section{Conclusion and discussion}

As the discussion of the three cases shows, the translation of financial reporting rules into prudential rules had a substantial impact on the engagement of banks in the shadow banking sector. Those countries that made proprietary trading off-balance sheet more expensive for banks were trying to regulate their banks out of this market. When prudential regulators were directly involved in the accounting standard-setting process, they pushed for stringent accounting rules that forced banks to account for the risks they took. This engagement can be linked to the relationship between the banking regulator and the central bank. Spain and France have prudential regulators that are either housed in the central bank or directly responsible to the central bank 
(France). In contrast, the German regulator was directly responsible to the finance ministry.

Another important difference lies in the legislative power of the accounting standard setter and the links between the standard setter and the political economy for which it legislates. At one extreme, the Spanish central bank is solely responsible for the accounting rules of banks and negotiates only with them. In France and Germany, the legislation in question was made in a different institutional setting that was more inclusive of stakeholders. The new legislative power, which the French standard setter gained in its reforms in 1996 and I998, and its concomitant effectiveness stands in comparison to the very weak position of the German standard setter in the process of accounting rule-making, especially its subordinated position with respect to the Ministry of Justice. In France, all stakeholders participate under the guidance of the standard setter. In contrast, in Germany, there was a much more disparate process in which industry associations were not directly engaged in the formulation of rules, but could instead veto the modernization of the rules at the level of the standard setter, the Ministry of Justice and Parliament. The direct subordination of the German financial regulator to the finance ministry and its exclusion from the standard-setting body contributed to a lack of engagement in the modernization of accounting rules to use them for prudential regulation. In contrast, in France, the prudential regulator was a central actor in the accounting standard setting for banks and the driving force behind the accounting rule changes regarding the business of banking groups with SPEs.

Lastly, the legislative heritage of traditionally different accounting norms for general corporations and the banking and insurance companies in France and Spain allowed for the faster convergence of French and Spanish rules. In contrast, the German heritage of general accounting rules generated a larger coalition of opponents, which made the modernization process more difficult. Off-balance sheet financing was not only important for banking groups but was also the reason for the existence of a large leasing industry, which saw its business model endangered by accounting changes.

This article has argued that, in order to be able to explain the large-scale variation of the impact of the international financial crisis on different European banking systems, scholars need to look at the national action of financial regulators interacting with international rules from within their specific national political economy of rule-making. On a substantive level, the importance of the interrelationship between accounting rules and prudential regulation has been elaborated. National accounting rules needed to change in order to force banks to be prudent in global markets. Therefore, in addition to analysing systemic influences of lobbies on an international level, scholars also need to look at the national level and particularly at the processes of accounting standard setting.

\section{Acknowledgements}

I want to thank the participants of the workshop "Risk, Arbitrage and Displacement Post-Crisis", the editor, the two anonymous reviewers and Tom DiPrete for helpful comments on earlier drafts of this paper. The remaining errors are of course my own. 


\section{Notes}

I Regulation is understood as "the organization and control of economic, political and social activities by means of making, implementing, monitoring and enforcing of rules» (s. Mattli and Walter 2008: I). Prudential regulation then is the attempt to make, implement, monitor and enforce rules which safeguard the financial system by deterring excessive risk taking which threatens the solvability of banks and the interconnected banking system.

2 Basel 2 is the successor to Basel I, the first international agreement on banking regulation. Negotiations began in 1996 and the final agreement was reached in 2004. Among others, Basel 2 introduced a more flexible system for the risk-weighting of assets and allowed banks to install their own risk-weighting systems to achieve this task. Most notably for this article, Basel 2 did not contain any specific rules on how to treat the securitization activities of banks, especially the question of how to treat special purpose entities that reappear on the balance sheets of banking groups. National regulators could adopt their own idiosyncratic measures. International bodies, such as the Committee of European Banking Supervisors, suggested in its non-binding guidelines in 2004 that these should be ignored if credit risk transfer from the bank to the SPE was achieved (see CEBS, 2004).

3 This difference clarifies that, while using the same construct, securities arbitrage conduits were disguised proprietary trading in complex securities, while multi-seller conduits served client needs.

4 The amount of capital to be withheld is calculated according to the perceived risk of the assets.

5 As Veron et al. (2004: 79) point out, those writing accounting rules are always engaged in a step by step fight in relation to fraud and the perversion of existing rules with ingenious financial engineers who constantly test the limits. In this sense, modernization can never be complete. With respect to special purpose entities, the international accounting standards were the first to introduce a new rule

capable of limiting the misuse of special purpose entities.

6 ROE means return on equity, which is the earnings after tax on shareholder equity.

7 Which is a 0.1 to 0.3 per cent margin.

8 Spanish banks were enjoying particularly strong profits in the decade before the crisis (almost quadrupling in absolute terms from 1999 to 2007 (see OECD, 2008), which reduced the pressure on the regulator to concede to the demands of banks.

9 CRC refers to the comité de la règlementation comptable, a smaller body inside the CNC that transposed proposals by the CNC into law. The full text of the CRC 99-02 can be found at: http:// www.articles.exafi.com/compta/ComptaTextes/ CRC99-02.htm.

Io The French text can be found at: http://www. bibliobaseonline.com/notice.php?NUMERO $=55893$ $\& \mathrm{OLD}={ }_{103092}$.

II Seventh Directive: Consolidated Accounts of Companies with Limited Liability, EEC 83/349: 4. Available at: http://eur-lex.europa.eu/LexUriServ/LexUriServ. do?uri=OJ:L:I983:I93:0001:0017:en:pdf.

I2 The French text can be found at: http://www2.budget. gouv.fr/fonds_documentaire/CNCompta/bocncomp ta/IIg.htm.

${ }^{2} 3$ The French text can be found at: http://www.banquefrance.fr/fr/supervi/regl 3e_bafi/textvig/reg6_2003. htm.

${ }^{14}$ The French text can be found at: http://www. amf-france.org/documents/general/4388_I.pdf.

${ }^{15}$ For the German law specifying this rule, see http:// www.bmi.bund.de/SharedDocs/Downloads/DE/ Veroeffentlichungen/ggo.pdf?_blob=publicationFile.

I6 The president of the standard setter warned, in the prestigious Börsenzeitung of July 2002, of the dangers of hidden Enrons in Germany, which required a modernization. See Havermann (2002).

${ }^{17}$ The German text can be found at: http://www. standardsetter.de/drsc/docs/comments/or6/bakred. html.

\section{References}

Acharya, V. \& Schnabl, P. 2009. How Banks Played the Leverage 'Game'. In: V.V. Acharya and M. Richardson, eds. Restoring Financial Stability: How to Repair a Failed System. New York: Wiley.

Acharya, V. \& Schnabl, P. 20Io. Do Global Banks Spread Global Imbalances? Asset-Backed Commercial Paper during the Financial Crisis of 2007-2009. IMF Economic Review, 58(I): 37-73.

Acharya, V. \& Suarez, G. 2009. Securitization without Risk Transfer. Working paper. New York: University Stern School of Business.

Aalbers, M., E. Engelen and A. Glasmacher. 20II. 'Cognitive closure' in the Netherlands: mortgage securitization in a hybrid European political economy. Environment and Planning A 20II, 43: I779-1795.

Amis, P. \& Rospars, E. 2005. Prudential Supervision and the Evolution of Accounting Standards: The Stakes for Financial Stability. Banque de France Financial Stability Review, 7: 47-58. 
Arteta, C., Carey, M., Correa, R. \& Kotter, J. 2009. Revenge of the Steamroller: ABCP as a Window on Risk Choices. Paper presented at the 2009 Financial Intermediation Research Society Meetings, Prague, pp. $27-29$.

Asmussen, J. 2006. Verbriefungen aus Sicht des Bundesfinanzministeriums. Zeitschrift für das gesamte Kreditwesen, S.IOI6-IOI8.

Banco de Espana. 2004. Circular 2004: Credit Institutions, Public and Confidential Financial Reporting Rules and Formats (English Version). Madrid: Banco de Espana.

Bannier, C. \& Haensel, D. 2009. Determinants of European Banks' Engagement in Loan Securitization. Working paper, Deutsche Bank.

Blundell-Wignall, A. \& Atkinson, P. 20ro. Thinking Beyond Basel 3: Necessary Solutions for Capital and Liquidity. Working Paper. Paris: OECD.

Bundesbank. 2008. Anfrage zum Thema Zweckgesellschaften. Informal release to the press.

Busch, A. 2009. Banking Regulation and Globalization. Oxford: Oxford University Press.

Coleman, W.D. 1996. Financial Services, Globalization and Domestic Policy Change. London: Macmillan.

Commission Bancaire. 2008. Annual Report Commission Bancaire. Available at: <http://www.banquefrance.fr/ $\mathrm{gb} /$ supervi/telechar/cbreport/annual-report-commission-bancaire-2008.pdf>

Committee of European Banking Supervisors (CEBS). 2004. Guidelines on Prudential Filters for Regulatory Capital. Available at: <http://www.eba.europa.eu/getdoc/dcb75Ic8-9d2I-4cf5-85 b7-6dod6d 5f5985/prudential_ filters-2I-Dec-2004.aspx>

Council of European Communities. I983. Seventh Council Directive 83/349/EEC, available at http:/eur-lex. europa.eu/LexUriServ/LexUriServ.do?uri=CELEX:31983Lo349:EN:HTML

Conseil National de la Comptabilite. I999. Bulletin Officiel nº I 9. http://www2.budget.gouv.fr/fonds_documentaire/ CNCompta/bocncompta/II 9. htm

Covitz, D., Liang, N. \& Suarez, G. 2009. The Evolution of a Financial Crisis: Panic in the Asset-backed Commercial Paper Market. Working Paper.

European Parliament and of the Council 2003. Directive 2003/5I EC, available at http://ec.europa.eu/internal_ market/accounting/officialdocs_en.htm

European Securitization Forum. 2002. Letter to IASB Regarding SIC I2. Available at: <http://www.europeanse curitisation.com/Advocacy/Comment_Letters/second_letter_to_iasb_sic_I2.pdf>

Financial Stability Forum. 2008. Report of the Financial Stability Forum on Enhancing Market and Institutional Resilience, accessible at HYPERLINK “http://www.financialstabilityboard.org/publications/r_0804.pdf” www. financialstabilityboard.org/publications/r_o804.pdf

Gorton, G.B. \& Souleles, N.S. 2006. Special Purpose Vehicles and Securitization: NBER Chapters. In: M. Carey and R.M. Stulz, eds. The Risks of Financial Institutions. Boston, MA: NBER Press, pp. 549-602.

Haensel, D. \& Krahnen, J.P. 2007. Does Credit Securitization Reduce Bank Risk? Evidence from the European CDO Market. Working paper, Universitaet Frankfurt.

Hardie, J. \& Howarth, D. 2009. Die Krise but not la crise? The Financial Crisis and the Transformation of the German and French Banking Systems. Journal of Common Market Studies, 47(5): 1017-1039.

Havermann, H. 2002. In Deutschland gibt es viele Enrons. Deutscher Standardsetter DSR plädiert für die vollständige Konsolidierung von Zweckgesellschaften, Börsenzeitung, ıо April.

Heilpern, E., Haslam, C. \& Andersson, T. 2009. When It Comes to the Crunch: What are the Drivers of the US Banking Crisis? Accounting Forum, 33: 99-II3.

Helleiner, E. and Porter, T. 2009. Making Transnational Networks More Accountable. In: S. Burke, ed. ReDefining the Global Economy. New York: Friedrich Ebert Stiftung Occasional Paper No. 42, pp. I4-24. Available at: <http://ibrary.fes.de/pdf-files/iez/global/o6293.pdf>

Hellwig, M. 20Io. Finanzmarktregulierung-Welche Regelungen empfehlen sich für den deutschen und europäischen Finanzsektor. Verhandlungen des 68. Juristentages. Verlag C.H. Beck München.

IMF. 2009. France: 2009. Article IV Consultation - Staff Report; Public Information Notice on the Executive Board Discussion; and Statement by the Executive Director for France. Washington, DC: IMF Publication Services.

Jeffrey, P. 2002. International Harmonization of Accounting Standards, and the Question of Off-balance Sheet Treatment. DUKE Journal of Comparative \& International Law, I2: 34I-35I.

Jouyet, J.P. 2009. L'avenir de la régulation financière. Revue de la stabilité financière, I3: 95-I08.

Larrson, R.K. 2008. Examination of Comment Letters Submitted to the IASC: Special Purpose Entities. Research in Accounting Regulation, 20: 27-47. 
Mattli, W. \& Woods, N. 2008. In Whose Benefit? In: W. Mattli and N. Woods, eds. The Politics of Global Regulation. Princeton, NJ: Princeton University Press, pp. I-43.

Moodys 2008. 2007 Review \& 2008 Outlook German/Austrian/Swiss Structured Finance: Strong start with slowdown in $\mathrm{H}_{2} 2007$.

Moran, M. I99I. The Politics of the Financial Services Revolution: The USA, UK and Japan. London: Palgrave Macmillan.

Noyer, C. 2009. Crise financière mondiale: stratégies publiques et privées pour faire face à la crise. Speech 2I January, Banque de France.

OECD. 2008. Banking Profitability: Financial Statements of Banks. Paris: OECD.

Polanyi, K. 1944. The Great Transformation: The Political and Economic Origins of Our Time. Beacon Press, by arrangement with Rinehart \& Company Inc., Boston.

Pozsar, Z., Adrian, T., Ashcraft, A. \& Boesky, H. 20I0. Shadow Banking. Federal Reserve Bank of New York Staff Reports, Staff Report no. 458, July.

Reinicke, W.H. I995. Banking, Politics and Global Finance. Aldershot: Edward Elgar.

Richerche e Studi (R\&S). 20Ir. Overview of Main Financial Stabilization Plans in Europe and the United States. Available at: <http://www.mbres.it/eng/download/rs_main_financial_stabilization_plans.pdf>

Standard and Poors. 20I0. Report Card: European ABCP Is Showing Resilience Despite The Downturn.

Streeck, W. 20Iо. Taking Capitalism Seriously: Toward an Institutionalist Approach to Contemporary Political Economy. MPifG Discussion Paper Io/15.

Tett, G. 2008. Insight: Spain's Banks Weather Credit Crisis. Financial Times, 3I January.

Tieman, R. 2009. Resilience Reinforces the Gallic Model. Financial Times, I7 December.

Tsingou, E. 2004. Policy Preferences in Financial Governance: Public-private Dynamics and the Prevalence of Market-based Arrangements in the Banking Industry. CSGR Working Paper No. I3I/04 (March).

Tsingou, E. 2008. Transnational Private Governance and the Basel Process: Banking Regulation and Supervision, Private Interests and Basel II. In: J.-C. Graz and A. Nölke, eds. Transnational Private Governance and its Limits. London: Routledge and ECPR, pp. 58-68.

Underhill, G.R.D. 20Io. Theory and the Market after the Crisis: The Endogeneity of Financial Governance. CEPR Discussion Paper No. DP8I64.

Underhill, G.R.D. \& Zhang, X. 2008. Setting the Rules: Private Power, Political Underpinnings, and Legitimacy in Global Monetary and Financial Governance. International Affairs, 84(3): 535-554.

Veron, N., Autret, M. \& Galichon, A. 2004. L'information financière en crise. Paris: Odile Jacob.

Ybanez, J. \& Garcia-Fuertes, G. 2005. Domestic Regulation and International Accounting Standards. Available at <http://www.internationallawoffice.com/newsletters/detail.aspx?g= ${ }_{5} \mathrm{~d} 76400 \mathrm{~d}-\mathrm{f}_{270}-4 \mathrm{~b} 7 \mathrm{~b}-\mathrm{af} 76$-fa $3 \mathrm{ffd}_{279362}>$

Zeitler, F.-C. 20Io. Finanzmarktkrise und Bankenaufsicht. In: S.G. Grieser und M. Heermann, eds. Bankenaufsichtsrecht, 20Iо. Frankfurt: Frankfurt School Verlag, pp. 3-I5.

\section{Notes on contributor}

Matthias Thiemann is a PhD candidate in the Sociology Department at Columbia University. There he is also an IGERT fellow in the Globalization and International Developments programme. He is the author of papers that have appeared in Soziale Systeme, UNDP Discussion Paper Series, the FEPS Working Paper Series and the New School Journal for Economics. He has been working as a UN consultant on the topic of international financial regulation and the policy space of developing countries in 20II. His research interests currently focus on the policy space for national financial regulators in an era of globalized finance, with special attention to nation states in the European Union.

Correspondence to: Matthias Thiemann, Columbia University Department of Sociology, 60I Knox Hall 606 West I22nd Street, New York, NY I0027, USA. Email: mt2430@columbia.edu 